Article

\title{
Current State of Technology of Fuel Cell Power Systems for Autonomous Underwater Vehicles
}

Alejandro Mendez ${ }^{1}$, Teresa J. Leo ${ }^{1, *}$ and Miguel A. Herreros ${ }^{2}$

1 Department of Sistemas Oceánicos y Navales, ETSI Navales, Universidad Politécnica de Madrid, 28040 Madrid, Spain; E-Mail: alejandro.mendezg@alumnos.upm.es

2 Department of Arquitectura y Construcción Navales, ETSI Navales, Universidad Politécnica de Madrid, 28040 Madrid, Spain; E-Mail: miguelangel.herreros@upm.es

$\dagger$ This paper is based on another one that was previously presented at the 1st International e-Conference on Energies, 14-31 March 2014.

* Author to whom correspondence should be addressed; E-Mail: teresa.leo.mena@upm.es; Tel.: +34-913-367-147; Fax: +34-915-442-149.

Received: 3 June 2014; in revised form: 8 July 2014 / Accepted: 16 July 2014 /

Published: 22 July 2014

\begin{abstract}
Autonomous Underwater Vehicles (AUVs) are vehicles that are primarily used to accomplish oceanographic research data collection and auxiliary offshore tasks. At the present time, they are usually powered by lithium-ion secondary batteries, which have insufficient specific energies. In order for this technology to achieve a mature state, increased endurance is required. Fuel cell power systems have been identified as an effective means to achieve this endurance but no implementation in a commercial device has yet been realized. This paper summarizes the current state of development of the technology in this field of research. First, the most adequate type of fuel cell for this application is discussed. The prototypes and design concepts of AUVs powered by fuel cells which have been developed in the last few years are described. Possible commercial and experimental fuel cell stack options are analyzed, examining solutions adopted in the analogous aerial vehicle applications, as well as the underwater ones, to see if integration in an AUV is feasible. Current solutions in oxygen and hydrogen storage systems are overviewed and energy density is objectively compared between battery power systems and fuel cell power systems for AUVs. A couple of system configuration solutions are described including the necessary lithium-ion battery hybrid system. Finally, some closing remarks on the future of this technology are given.
\end{abstract}


Keywords: AUV; UUV; fuel cell; underwater vehicle; hydrogen

\section{Introduction}

Autonomous Underwater Vehicles (AUVs) are unmanned underwater vehicles that are used to accomplish various missions autonomously, most commonly imaging of the ocean environment and ocean floor, oceanographic data collection, offshore applications and submarine cable applications [1,2]. There are two general types of AUVs. The torpedo-like survey AUVs and the highly maneuverable hovering AUVs. The former are the ones that are dealt with in this article, due to the fact that there has not been any documented development of fuel cell technology on hovering AUVs.

When a mission for an AUV is proposed the first thing that must be done is to define the requirements that will enable the vehicle to accomplish the tasks that are required for said mission. These requirements generally include the nominal speed, the maximum depth, the payload necessary for the mission and the endurance. All of these requirements affect each other, but the endurance is directly related to the energy storage, that is part of the power system, and is limited by the existing technology

The standard power system currently used in AUVs is secondary batteries (lithium-ion), and in some cases aluminum semi fuel cells are also used [3]. Secondary batteries are a simple and relatively inexpensive solution, and provide enough power for current applications. However, they suffer from limited energy capacity, which greatly limits their autonomy and the missions they can be used for. Fuel cells, unlike batteries, store their reactants outside of their structure and have as much energy as reactant can be stored. For this reason they have greater specific energies than batteries, as will be shown, even when taking into account the weight from the additional components such as storage tanks, pumps and blowers.

Despite the benefits they would provide, there are currently no commercial AUVs powered by a fuel cell system, or a hybrid fuel cell system. This is because the technology still requires further development, and this has a significant associated cost. Because of this reason, and also because of the strategic importance of this technology, there recently has been a concentrated effort from the Office of Naval Research, of the United States Department of the Navy to fund through contracts and research grants several companies to achieve progress in this area. In addition, fuel cells have been successfully implemented in UAV (unmanned aerial vehicle) and in automobiles, both of which have similarities to AUVs in that they also require a compact integrated power system.

There have been several prototypes and concept designs which are discussed in this article. Greater emphasis will be given to the proton exchange membrane fuel cells (PEMFC) because they have been successfully demonstrated for use in AUVs. Direct methanol fuel cells (DMFC) have low energies, solid oxide fuel cells (SOFC) require temperatures that are too high, alkaline fuel cells require ultra-pure hydrogen and oxygen so they are not developed for commercial use, and the phosphoric acid fuel cells (PAFC) and molten carbonate fuel cells (MCFC) are not compact enough [4].

This manuscript describes the state of the art of fuel cell technology in AUVs. The most important fuel cell powered AUV prototypes and bench fuel cell power systems will be described. Current fuel 
cell stack technology and reactant storage systems will be explored. Afterwards, hybrid secondary battery-fuel cell power system options will be evaluated and an overview of the complete power system configuration will be given. Finally, specific and volumetric energy parameters of the entire power system, for different storage system configurations will be estimated for a typical AUV, using data collected by different stack manufacturers and research publications.

\section{AUV Fuel Cell Power Systems: Current Situation}

\subsection{Prototypes}

\subsubsection{Urashima (JAMSTEC and Mitsubishi Heavy Industries)}

Urashima was an experimental AUV powered by PEFC and lithium ion cells as an auxiliary power source. It started development in 1998 by the Japan Agency for Maritime Earth Science and Technology (JAMSTEC) [5]. The AUV weighs 10 tons, is $10 \mathrm{~m}$ in length and $1.4 \mathrm{~m}$ in diameter. It has a $300 \mathrm{~km}$ cruise capacity and can dive up to $3500 \mathrm{~m}$ depth [6]. Its fuel cell power system has two $2 \mathrm{~kW}$ fuel cell stacks at $120 \mathrm{~V}$ [7], and was developed by Mitsubishi Heavy Industries Ltd. (Tokyo, Japan) [5]. It is part of a hybrid system, which also has a 30 Ah lithium-ion battery, used for dealing with peak power demands that the fuel cell cannot supply [8].

The system configuration includes the fuel cell stacks, humidifier, heat exchanger, reaction water tank, oxygen tank and fuel tank. There are two pressure vessels, one for the fuel cell stack and its auxiliaries which is made of titanium alloy [9] and the other one for the hydrogen fuel as AB5 alloy metal hydride (for each $1 \mathrm{~kg}$ of hydrogen, $66 \mathrm{~kg}$ of hydride is required) [10]. There is also an independent pressurized oxygen tank. The metal hydride releases the hydrogen using heat transferred from the stack through water [6].

In September 2003, a $21 \mathrm{~km}$ six hour sea trial was done using fuel cell only [6]. In June 2004, a $220 \mathrm{~km}, 44 \mathrm{~h}$ cruise was done in four trips among transponders [11]. In February 2005, a $56 \mathrm{~h} 317 \mathrm{~km}$ autonomous cruise was performed continuously at a depth of $800 \mathrm{~m}$, with an average speed of $1.55 \mathrm{~m} / \mathrm{s}$ (3 knots) [9].

The developers had identified certain issues with the Urashima power system, which they are currently working to improve. These included slow start up, the blowers for reactant circulation did not work well, there was considerable hydrogen leakage and the system was too large [12].

\subsubsection{Second Generation Long Cruising AUV (JAMSTEC and Mitsubishi Heavy Industries)}

It is a second generation long cruising range AUV currently being developed by JAMSTEC. It was required by its developers to possess $600 \mathrm{~h}$ endurance, $3000 \mathrm{~km}$ range, $10 \mathrm{~kW}$ power and $5000 \mathrm{kWh}$ capacity. A desktop PEMFC prototype for the AUV's fuel cell power system has been developed. This fuel cell system is called HEML (High-Efficiency Multi-Less) FC, and is a novel concept that changes and is supposed to improve from standard fuel cell stack design and operation. This is done by eliminating recirculation blowers and replacing them by valves. Eliminating also humidifiers by improving materials and MEA composition, and reducing hydrogen leakage [13]. 
The desktop model was completed in 2009 to test the new concept. An operation time of over $1000 \mathrm{~h}$ was accomplished as well as operating efficiencies of $60 \%$. In October 2010 a fuel cell system prototype consisting of two $150 \mathrm{~W}$ fuel cell stacks, an electronic controller and a pressure vessel was completed, and in January 2011 it achieved $600 \mathrm{~h}$ continuous electric power generation. In March 2011, a successful sea-trial of the prototype installed on a deep tow was done, with success in generating electricity during the sea trial [13]. In November 2013, the fuel cell system was successfully installed on JAMSTEC's "Deep Tow" research towing unit. The system was submerged to a depth of $180 \mathrm{~m}$ and supplied power to two units of observation equipment. The developers reported that power was supplied stably and that the equipment being supplied functioned without interruption [14].

\subsubsection{DeepC}

DeepC is an experimental German AUV development project conducted by a consortium coordinated by STN ATLAS Elektronik. It was funded by the German Federal Ministry for Education and Research [5]. It had requirements of two to four tons weight, $2 \mathrm{~m} / \mathrm{s}$ (4 knots) cruising speed, $60 \mathrm{~h}$ endurance and $4000 \mathrm{~m}$ mission depth. The vehicle has three connected hulls, two identical propulsion hulls and one for the payload [15].

This AUV possessed a hybrid battery-PEM fuel cell system, with the batteries taking peak loads. The fuel cell system consisted of two 30 cell stacks with a total output of $3.6 \mathrm{~kW}$ and each located inside each of the two propulsion hulls. Due to safety reasons they are located in a gas proof chamber with a pressure relief valve. The hydrogen and oxygen are stored in pressure gas bottles of 250 bar and 350 bar allowing for a total electrical energy of $140 \mathrm{kWh}$ to be obtained [15].

\subsubsection{IDEF Ifremer}

It is an experimental AUV powered by PEM fuel cell adapted to an existing AUV. It weighs 1.6 tons and has $6 \mathrm{~m}$ length. The fuel cell system was designed by the HELION firm, a subsidiary of the Areva group. The PEM fuel cell stack is composed of 63 cells, and produces $1.5 \mathrm{~kW}$. Its system efficiency including auxiliaries' consumption is 55\%. Hydrogen and oxygen gases are recirculated and full reactant conversion is achieved. The system is located in an aluminum pressure vessel which is pressurized with nitrogen so as to prevent gas leaks and explosive hydrogen-oxygen mixtures. The hydrogen and oxygen are stored in $50 \mathrm{~L}$ pressure gas bottles, two 300 bar hydrogen ones, and a 250 bar oxygen, allowing for a total electrical energy of $36 \mathrm{kWh}$. The IDEF AUV has a $300 \mathrm{~km}$ range, it dived seven times in October 2009, with gas refills before each one, reaching depths of $400 \mathrm{~m}$ [16].

\subsection{Conceptual Designs}

\subsubsection{Underwater Glider Dragon}

Underwater glider designed by the School of Mechanical Engineering Tianjin University to surpass the performance of established commercial gliders, including nominal power ratings and endurances. It would weigh $70 \mathrm{~kg}$, have $2.3 \mathrm{~m}$ length, $22 \mathrm{~cm}$ diameter, and PEMFC volume of $6500 \mathrm{~cm}^{3}$.

A test was done to determine the efficiency and feasibility of a PEMFC system, using a stack that has a $12 \mathrm{~V}$ voltage rating and a power rating of $100 \mathrm{~W}$. It has a $32 \mathrm{~cm}^{2}$ Nafion membrane. 
Two hydrogen and two oxygen tanks were adopted. The excess gas of the fuel cell would recirculate in the system by jet pump and the reacted water would be collected [17]. There has not been a prototype of this system yet.

\subsubsection{Seahorse}

Pennsylvania State University ARL (Applied Research Laboratory) has investigated the use of fuel cells for undersea propulsion applications, particularly for AUV's and for hybrid torpedoes. They have worked on a 400 W PEM Cell at ARL's Energy Science and Power Systems Division. ARL has a large battery powered AUV called "Seahorse" that may be converted to fuel cell operation. The fuel cell system was never operated in the Seahorse $[18,19]$. Oxygen would be supplied by converting lithium perchlorate $\left(\mathrm{LiClO}_{4}\right)$ to oxygen using technology developed by ARL/Penn State.

\subsection{Office of Naval Research (ONR) Large AUV Development}

The ONR is an office of the United States Department of the Navy that is in charge of the U.S Navy and Marine Corps science and technology programs. They have been involved in AUV development since the technology's early stages. They have been especially interested in developing a large AUV, capable of possessing greater endurances [20]. For this very reason, they have also invested resources in developing fuel cell power systems for AUVs. One of the ways they have done this is by announcing a formal request for proposals on technology for Long Endurance Undersea Vehicles, in March 2011. The winners of the awards would be provided with grants or contracts for project funding. The total funding amount was 18 million dollars over a five-year period. The projects would be developed following a three phase scheme in which a series of project objectives would have to be achieved. In this document they also set forth objective metrics for the power system which would also have to be achieved. Among these metrics were a $20 \mathrm{~W} / \mathrm{L}$ nominal power density requirement, $76.2 \mathrm{~cm}$ energy section max length, an energy content of $68 \mathrm{kWh}$, and an endurance of over $30 \mathrm{~h}$ [21]. Table 1 includes projects the ONR has been involved in.

Table 1. Projects the Office of Naval Research (ONR) has been involved in (based on [4,22-32]).

\begin{tabular}{ll}
\hline \multicolumn{1}{c}{ Project } & \multicolumn{1}{c}{ Description } \\
\hline & In the early nineties, UTC, then called International Fuel Cells (IFC) sponsored by the \\
UTC Aerospace Systems & Defense Advanced Research Projects Agency (DARPA) developed a 4 stack, \\
for 44-in AUV & $15 \mathrm{~kW}$ PEM fuel cell system for a $1.12 \mathrm{~m}$ (44 inch) diameter AUV. The system was tested \\
& in the laboratory for over 500 h. It was never used at sea [4,22,23]. \\
& UTC is developing an energy dense, air independent rechargeable energy system for a Large \\
UTC Aerospace Systems & AUV (LAUV), based on a PEM fuel cell developed for an air independent submarine \\
AUV Power and energy & propulsion system. It uses cryogenic energy storage system and a simplified balance of \\
storage system & plant, with minimal moving parts [24]. \\
\hline
\end{tabular}


Table 1. Cont.

\begin{tabular}{|c|c|}
\hline Project & Description \\
\hline $\begin{array}{l}\text { UTC S-80 Fuel Cell } \\
\text { Power Module (FCPM) }\end{array}$ & $\begin{array}{l}\text { UTC has developed a power system that provides } 300 \mathrm{~kW} \text { of electrical power from a PEM } \\
\text { Fuel Cell on Navantia's S- } 80 \text { Air Independent Propulsion (AIP) submarine for the Spanish } \\
\text { Navy. It uses reformed bio-ethanol for } \mathrm{H}_{2} \text {, and oxygen from liquid oxygen [25]. }\end{array}$ \\
\hline $\begin{array}{l}\text { API Engineering LLC } \\
\text { and Nextech Materials } \\
\text { Oxygen source for air } \\
\text { independent AUV SOFC } \\
\text { power sources }\end{array}$ & $\begin{array}{l}\text { A } 2.5 \mathrm{~kW} \text { SOFC power system for a } 54 \mathrm{~cm} \text { ( } 21 \mathrm{inch}) \mathrm{AUV} \text { is currently being developed by } \\
\text { API Engineering LLC and Nextech Materials, through the grants obtained from ONR in } \\
2011 \text {, worth more than } \$ 500,000 \text {. The system is based on an innovative oxygen source that } \\
\text { uses an aqueous chlorate solution for its oxygen storage composition. The integrated system } \\
\text { requires less than } 19 \text { inches of length to provide } 50 \mathrm{~kg} \text { of deliverable oxygen in a } 54 \mathrm{~cm} \\
\text { AUV [26,27]. }\end{array}$ \\
\hline $\begin{array}{l}\text { General Atomics and } \\
\text { Infinity LAUV }\end{array}$ & $\begin{array}{l}\text { General Atomics funded by the ONR is in the Phase } 1 \text { of the development of a } \\
5 \mathrm{~kW} \text { PEM power system which comprises a timespan from July } 2012 \text { until January } 2014 \text {. } \\
\text { The air independent PEM stack is being developed by Infinity, and features passive water } \\
\text { removal which allows for a compact and simple balance of plant directly to the fuel cell } \\
\text { stack and plates [28]. They have successfully tested a } 1 \mathrm{~kW} \text { stack during a } 40 \mathrm{~h} \text { continuous } \\
\text { test [29]. }\end{array}$ \\
\hline Lynntech, Inc LAUV & $\begin{array}{l}\text { Lynntech is developing a long endurance air-independent fuel cell power system for a } 54 \mathrm{~cm} \\
\text { (21 inch) diameter AUV using a proprietary chemical hydride fuel source and hydrogen } \\
\text { peroxide for oxidant acquisition [30]. }\end{array}$ \\
\hline $\begin{array}{l}\text { Sierra Lobo Cryogenic } \\
\text { Reactants Energy } \\
\text { System }\end{array}$ & $\begin{array}{l}\text { Sierra Lobo was awarded a } \$ 3.9 \text { million contract from the ONR to develop, fabricate, and } \\
\text { test a fuel cell and cryogenic reactants energy system. The system uses liquid hydrogen as } \\
\text { the fuel, liquid oxygen as the oxidizer, and a Teledyne Energy Systems PEM fuel cell for } \\
\text { power generation [31]. }\end{array}$ \\
\hline $\begin{array}{l}\text { FuelCell Energy, Inc } \\
\text { SOFC power system } \\
\text { for LAUV }\end{array}$ & $\begin{array}{l}\text { FuelCell Energy, Inc. received in } 2012 \text { a } \$ 3.8 \text { million contract award from the ONR, for a } \\
\text { SOFC-Battery power system for large displacement undersea vehicle propulsion. The } \\
\text { Hybrid SOFC-Battery system would be capable of generating } 1800 \mathrm{kWh} \text { of electricity } \\
\text { during a } 70 \text { day mission according to reference [32]. It will use liquid fuel and be } \\
\text { self-contained with no reliance on external air. This } 18 \text { month phase I award will fund } \\
\text { development and laboratory testing of the SOFC propulsion system. }\end{array}$ \\
\hline
\end{tabular}

\subsection{Fuel Cell Stacks}

The fuel cell stack is the power generating component of the power system. Given the mass and volume constraints imposed on an AUV, specific energy and energy density arise as two of the main design variables.

Due to the fact that there hasn't yet been a commercial fuel cell powered AUV, there also hasn't been a commercial fuel cell stack developed specifically for this application. Instead, standard stacks have been adapted for use in AUVs in some cases, such as the IDEF AUV and the Seahorse concept. Another example of a stack adapted for an underwater application is the $3 \mathrm{~kW}$ one that Ballard supplied the Perry PC-14 submersible and the Ballard-Mark-V 35-cell $5 \mathrm{~kW}$ PEM stack which has been studied for AUVs [33]. In other cases, novel designs have been used. This is the case of the stack that JAMSTEC is currently developing, and also of a few firms which have received financing from the defense industry and are also developing their own systems, as has been mentioned in the previous section. 
This lack of maturity for this concrete application entails a lack of application specific data with which to assess system performance. This can nevertheless be bridged by comparing data from similar applications such as fuel celled powered UAVs (unmanned aerial vehicle) and fuel cell hydrogen vehicles to a lesser extent.

UAVs impose very similar conditions on their power systems in terms of mass and volume constraints, with a big difference being that UAVs do not require oxygen storage due to the availability of oxygen in the atmosphere. Several small size UAVs, powered by fuel cells, exist. They are usually lighter than a similar AUV would be, due to the higher speeds required, and thus have higher thrust power/total vehicle mass ratio. Despite this fact, since AUVs are currently operated at slow speeds $1-2.5 \mathrm{~m} / \mathrm{s}(2-5 \mathrm{knots})$ the power range of both types of vehicles is similar (approximately from $200 \mathrm{~W}$ to $3 \mathrm{~kW})$.

Fuel cell powered UAV systems that stand out due to their performance include Protonex Technology's Protonex ProCore fuel cell system, used to power the UAV Puma, which flew continuously for more than $7 \mathrm{~h}$ [34]. More impressive is the UAV-H500 PEM fuel cell power system they have developed. This system is a commercial variant of the one used to set a flight record of over $26 \mathrm{~h}$ in an Ion Tiger UAV [35]. In addition, Horizon Fuel Cell Technologies high-performance hydrogen fuel cell power system which is used in the UAV Boomerang, a $9 \mathrm{~kg}$ electric UAV, is able to fly for more than $9 \mathrm{~h}$ [34]. A summary of the fuel cell powered UAV application can be found in [36].

In Table 2 several stack specifications of commercial fuel cells and fuel cells used in AUVs are presented. Most of these commercial stacks, include integrated balance of plant components such as blowers, cooling system, valves. Additionally, some are self-humidified and some of them are scalable to different power needs.

Table 2. Fuel cell stack specifications (based on [19,36-46]).

\begin{tabular}{|c|c|c|c|c|c|}
\hline Manufacturer/Model & $\begin{array}{c}\text { Fuel Cell } \\
\text { Weight (kg) }\end{array}$ & $\begin{array}{l}\text { Fuel Cell Dimensions } \\
(\mathrm{mm}) \text { or volume (L) }\end{array}$ & $\begin{array}{c}\text { Specific } \\
\text { Power } \\
\text { (W/kg) } \\
\end{array}$ & $\begin{array}{c}\text { Power } \\
\text { Density } \\
(\mathrm{W} / \mathrm{L}) \\
\end{array}$ & Remarks \\
\hline \multicolumn{6}{|c|}{ Stacks used in AUV prototypes } \\
\hline $\begin{array}{l}\text { UBZM Gmbh-BZ100 } \\
\text { (1200W standard) }\end{array}$ & $\begin{array}{c}0.32 \mathrm{~kg} / \text { cell } \\
\text { (with } 48 \text { cells) }\end{array}$ & $(180-520) \times 145 \times 125$ & 78 & 127 & $\begin{array}{l}\text { UBZM Gmbh related to } \\
\text { ZSW, manufacturer of } \\
\text { DeepC PEMFC }\end{array}$ \\
\hline MHI Urashima FC Stack & - & - & 150 & - & - \\
\hline \multicolumn{6}{|c|}{ Stacks used in UAV applications } \\
\hline ProtonexProCore & 2.7 & 2.8 & 74 & 71.5 & Spider Lion UAV \\
\hline Protonex UAV C-250 & 1.2 & 1.35 & 208 & 185 & - \\
\hline $\begin{array}{l}\text { Protonex Ion Tiger } \\
\text { UAV (NRL) }\end{array}$ & 1 & - & 550 & - & - \\
\hline EnergyOr 310-XLE & 3.95 & - & 78.5 & - & $\begin{array}{c}\text { Mass includes H2 fuel and } \\
\text { storage. Radiant Coral } \\
\text { Technologies UAV }\end{array}$ \\
\hline EnergyOr 210-XLE & 3.65 & - & 57.5 & - & - \\
\hline $\begin{array}{l}\text { Horizon AEROSTACK } \\
\text { A-1000 PEM FUEL CELL }\end{array}$ & 1.75 & $275 \times 135 \times 120$ & 571 & 224 & $\begin{array}{l}\text { With fan and casing, } \\
\text { self-humidified }\end{array}$ \\
\hline
\end{tabular}


Table 2. Cont.

\begin{tabular}{|c|c|c|c|c|c|}
\hline Manufacturer/Model & $\begin{array}{c}\text { Fuel Cell } \\
\text { Weight (kg) }\end{array}$ & $\begin{array}{l}\text { Fuel Cell Dimensions } \\
(\mathrm{mm}) \text { or volume (L) }\end{array}$ & $\begin{array}{l}\text { Specific } \\
\text { Power } \\
(W / k g) \\
\end{array}$ & $\begin{array}{c}\text { Power } \\
\text { Density } \\
(W / L) \\
\end{array}$ & Remarks \\
\hline $\begin{array}{c}\text { Horizon AEROSTACK A-500 } \\
\text { PEM FUEL CELL 500W }\end{array}$ & 1.15 & $192 \times 107 \times 150$ & 434 & 162 & $\begin{array}{l}\text { With fan and casing, } \\
\text { self-humidified }\end{array}$ \\
\hline $\begin{array}{l}\text { Horizon AEROSTACK A-200 } \\
\text { PEM FUEL CELL 200W }\end{array}$ & 0.5 & $120 \times 80 \times 75$ & 400 & 278 & $\begin{array}{l}\text { With fan and casing, } \\
\text { self-humidified }\end{array}$ \\
\hline $\begin{array}{l}\text { Horizon Stack for HyFish UAV } \\
\text { United Technologies Research }\end{array}$ & 3 & - & 334 & - & - \\
\hline $\begin{array}{l}\text { Center (UTRC) Stack for FC } \\
\text { rotorcraft }\end{array}$ & 1.78 & - & 675 & - & - \\
\hline $\begin{array}{c}\text { Lynntech Gen IV } 5 \mathrm{~kW} \text { stack } \\
\text { for Helios UAV }\end{array}$ & 20 & 19 & 250 & 263 & - \\
\hline \multicolumn{6}{|c|}{ Commercial stacks } \\
\hline Ballard FCgen-1020ACS & $\begin{array}{c}0.196 \mathrm{~kg} / \mathrm{cell} \\
56 \text { cell } \\
\text { standard }\end{array}$ & $(110-495) \times 103 \times 351$ & 230 & 192 & $\begin{array}{c}\text { Air cooled. Scalable. } \\
\text { Self-humidifying membrane. }\end{array}$ \\
\hline Horizon H-500XP & 5.8 & $150 \times 203 \times 52$ & 86 & 316 & $\begin{array}{c}\text { With blower, } \mathrm{H} 2 \text { supply and } \\
\text { purge valve }\end{array}$ \\
\hline Horizon H-1000XP & 5.9 & $203 \times 104 \times 264$ & 169 & 179 & $\begin{array}{c}\text { With blower, } \mathrm{H} 2 \text { supply and } \\
\text { purge valve }\end{array}$ \\
\hline Horizon H-300 & 2.79 & $118 \times 262 \times 94$ & 108 & 103 & $\begin{array}{l}\text { With fan and casing, } \\
\text { self-humidified, and blower }\end{array}$ \\
\hline Horizon H-500 & 2.52 & $268 \times 130 \times 122.5$ & 196 & 117 & $\begin{array}{l}\text { Blower, electronic valves, } \\
\text { self-humidified, fan, }\end{array}$ \\
\hline Horizon H-1000 & 4 & $268 \times 219 \times 122.5$ & 250 & 139 & $\begin{array}{l}\text { Blower, electronic valves, } \\
\text { self-humidified, fan, }\end{array}$ \\
\hline Horizon H-2000 & 10 & $350 \times 183 \times 303$ & 200 & 103 & $\begin{array}{l}\text { Blower, electronic valves, } \\
\text { self-humidified, fan, }\end{array}$ \\
\hline AREVA Helion $20 \mathrm{~kW}$ & 160 & $690 \times 470 \times 335$ & 125 & 182 & - \\
\hline Nedstack HP 2.0 & 15 & $217 \times 194 \times 288$ & 133 & 18.4 & - \\
\hline Nedstack HP 5.0 & 22 & $353 \times 194 \times 288$ & 227 & 254 & - \\
\hline Siemens BZM 34 kW & 650 & $480 \times 480 \times 1450$ & 52 & 102 & $\begin{array}{l}\text { Stack }+ \text { balance of } \\
\text { plant components }\end{array}$ \\
\hline Siemens BZM $120 \mathrm{~kW}$ & 900 & $500 \times 530 \times 1760$ & 133 & 257 & $\begin{array}{l}\text { Stack + balance of } \\
\text { plant components }\end{array}$ \\
\hline
\end{tabular}

\subsection{Storage}

Reactant storage is an important issue in an AUV power system, due to the fact that it has a direct impact on the endurance, and on the efficiency of the power plant itself. More efficient storage designs are those which have higher specific energy and energy density. Hydrogen and oxygen storage for fuel cell powered AUVs is an active field research, as evidenced by the ONR's funded research projects previously mentioned in this article. In this section the main reactant storage options used in AUVs will be overviewed, and representative energy content values will be presented. 
High pressure gas storage of reactants is a straightforward simple solution to the storage problem but it imposes big, heavy containers. Liquid storage of the reactants on the other hand is more efficient and has the lowest weight and volume but presents difficulties like required low temperatures, high cost and greater system complexity. Metal hydride storage can be a simple solution for hydrogen storage, but these are the heaviest due to the fact that there are atoms other than hydrogen that are part of the system [47].

\subsubsection{Hydrogen Storage}

In Table 3, ranges of specific energies and energy densities of different hydrogen storage systems obtained in [19] are shown. An important issue that arises when dealing with hydrogen is the fact that hydrogen leakage is very high. This fact has to be taken into account for safety reasons when designing the system in order to reduce it to acceptable levels [47].

\subsubsection{Gaseous Hydrogen}

Compressed Hydrogen offers the simplest and least expensive solution to fuel storage and it also has the advantage of not needing preprocessing [48]. Since gaseous hydrogen has a very low energy density, high pressures are usually applied (up to 700 bar), in order to maximize hydrogen content [19], which requires the use of very heavy storage vessels in order to avoid mechanical failure due to the high pressures. The hydrogen bottles can be made out of high strength steel, aluminum or composite fiber [48]. For compressed hydrogen specific energies vary between $1.1 \mathrm{kWh} / \mathrm{kg}$ and $1.7 \mathrm{kWh} / \mathrm{kg}$ and energy densities between $0.5 \mathrm{kWh} / \mathrm{L}$ and $0.7 \mathrm{kWh} / \mathrm{L}$ [19]. Operational difficulties that must be taken into account are that tanks suffer from hydrogen embritlement after several recharges [4], and are an explosive hazard if not handled properly [49].

\subsubsection{Liquid Hydrogen}

Liquid Hydrogen has a higher energy density than gaseous, but still low. They require very low temperatures, less than $20.15 \mathrm{~K}$, so they must be stored in cryogenic Dewars, which are multi shell flasks using an evacuated interstitial space and multi-layer Mylar insulation to reduce heat transfer through the flask and avoid boil off of the gas. Fuel processing in this case is through gas vaporization [48], this occurs naturally to a certain extent due to heat transfer from the fuel cell and the surrounding ocean water. As long as the natural vaporization rate is less than that of consumption the system is stable and no fuel would need to be wasted [19]. In addition, boil-off losses happen during refueling and storage [47]. This storage method has several issues, like high cost and complexity and safety concerns [48]. There are also logistics issues, such as limited availability and refueling, which requires special equipment and skills [47]. With this solution values of $1.6 \mathrm{kWh} / \mathrm{kg}$ and $1.2 \mathrm{kWh} / \mathrm{L}$ with liquid hydrogen storage have been obtained [19].

\subsubsection{Hydrocarbons and Chemical Sources}

Hydrocarbon sources are cheap, common hydrogen carrying liquids, but add complexity, weight and volume. The most common options are methanol, kerosene and diesel. They require being 
reformed with steam at high temperatures. The steam carries hydrogen $(70 \%-75 \%), \mathrm{CO}_{2}, \mathrm{CO}$, and water. Sulfur must be completely removed from the fuel so as to not affect the reformer catalyst. CO must also be removed to avoid the fuel cell's platinum catalyst's degradation. Hydrodesulphurization for eliminating the sulfur content requires the use of expensive a complex reforming equipment. An issue that arises in undersea reforming systems is that carbon dioxide produced by the reforming process must be disposed of or stored [48].

\subsubsection{Rechargeable Metal Hydrides}

They are metal alloys that react reversibly with hydrogen, storing it at low pressures [50]. By heating the hydride hydrogen is liberated from the alloys structure. Metal hydrides have a good energy density but a very low specific energy. Usually is less than $3.6 \%$ hydrogen by weight. Their heavy weight limits their applications, making them feasible only for large vehicles. They suffer from high cost and sensitivity to water, carbon monoxide, and oxygen [48] and also lose storage efficiency over multiple cycles [4]. Hydrogen production rates can be controlled making it the safest medium.

\subsubsection{Chemical Hydrides}

Chemical hydrides are used to generate $\mathrm{H}_{2}$ either by hydrolysis or by pyrolysis, which involves applying heat. They have the advantages of having high hydrogen content and of not requiring a complex and voluminous feed regulation system. Examples of compounds that use hydrolysis are $\mathrm{NaBH}_{4}, \mathrm{NaAlH}_{4}, \mathrm{LiBH}_{4}$ and $\mathrm{LiH}$, while $\mathrm{NH}_{3} \mathrm{BH}_{3}$ and $\mathrm{NH}_{4} \mathrm{BH}_{4}$ are examples of compounds that suffer decomposition by pyrolysis. Reference [51] compares several hydrogen storage options and based on the available manufacturer data determined that a $\mathrm{NH}_{3} \mathrm{BH}_{3}$ solution (which is still under development) gave the greatest endurances of all, presenting values of $0.11 \mathrm{~kg} \mathrm{H} / \mathrm{kg}$.

Table 3. Hydrogen storage system energy content (based on [19]).

\begin{tabular}{ccc}
\hline Storage Type & Energy Density $(\mathbf{W h} / \mathbf{L})$ & Specific Energy $(\mathbf{W h} / \mathbf{k g})$ \\
\hline Compressed gas & $560-700$ & $1100-1710$ \\
Liquid $\mathrm{H}_{2}$ & 1220 & 1620 \\
Metal Hydrides & $770-1670$ & $280-520$ \\
\hline
\end{tabular}

\subsubsection{Oxygen Storage}

Unlike in conventional fuel cells, underwater fuel cells require oxygen storage because atmospheric air is not available. This oxygen usage increases stack performance two to three times. In addition, excess oxygen is required to carry away the product water from the stack, which has to be considered when sizing this system [51]. Oxygen storage will be evaluated in terms of energy density and specific energy [19] and ranges of values for different storage systems from the same reference are shown in Table 4. The oxygen storage can be evaluated in terms of these parameters, taking into account the stoichiometric ratio of the fuel cell reaction. 


\subsubsection{Chemical Storage}

Oxygen is released due to an exothermic chemical reaction, through thermal or catalytic processes. It's less efficient because there are non-oxygen atoms and also unreleased oxygen, so it possesses a higher system weight $[4,49]$. Common chemicals that can be used include Sodium chlorate, lithium perchlorate, other oxyhalides, or peroxides/superoxides. This solution presents the problem that highly oxidizing chemicals must be stored and dealt with when refueling [4].

\subsubsection{Pure Oxygen}

High pressure oxygen has the simplest delivery mechanism. Required tank wall thickness increases with pressure, which in turn decreases the energy density advantages [4]. Tanks up to 690 bar can be commercially obtained. Lightweight compressed oxygen tanks for transport applications are not as developed as hydrogen due to the fact that air is usually used in terrestrial hydrogen vehicles. Compressed oxygen storage energy density values ranges between $0.5 \mathrm{kWh} / \mathrm{L}$ and $1 \mathrm{kWh} / \mathrm{L}$, and specific energy content reaches values up to $2 \mathrm{kWh} / \mathrm{kg}$ [19]. This technology has been successfully implemented in the AUV Urashima prototype [52].

\subsubsection{Cryogenic Liquid Oxygen (LOX)}

LOX is the optimal solution for limited space applications. There is higher complexity due to the need for safety conditions in handling and storage. Refueling requires special equipment and skills [4]. The boiling point of oxygen is $90.18 \mathrm{~K}$ and boiling losses when refueling and during storage must be considered [47].

Sierra Lobo, Inc., designed a LOX storage system prototype for a $54 \mathrm{~cm}$ (21 inch) diameter AUV [19]. It works with a $1 \mathrm{~kW}$ output PEM fuel cell and stores $50 \mathrm{~kg}$ of LOX at $94 \mathrm{~K}$. The system dimensions are $0.94 \mathrm{~m}$ long, $0.32 \mathrm{~m}$ in diameter and $13.6 \mathrm{~kg}$ weight when empty (and $63.6 \mathrm{~kg}$ when full) [10].

Table 4. Oxygen storage system energy content (based on [19]).

\begin{tabular}{ccc}
\hline Storage Type & Energy Density (Wh/L) & Specific Energy (Wh/kg) \\
\hline LOX & $2780-2980$ & $2900-3300$ \\
Chemical & $1340-2090$ & $1170-1300$ \\
Compressed & $600-1090$ & $770-1680$ \\
\hline
\end{tabular}

\subsection{System Configuration}

The fuel cell power system is composed of a fuel cell stack, oxygen and hydrogen supply systems, the cooling system, the humidification system and the electrical subsystems. The oxygen and hydrogen supply systems are composed of the storage mechanism, pressure regulator, humidifier, water separator and recirculation pump. If the reactants are fed passively they do not require feeding regulation because they are fed as they are consumed in the stack. Otherwise a blower and regulation are used. Recirculation improves the reactant usage and removes impurities and condensing water from the stack. Humidification of reactants is necessary to maintain the MEA hydrated. Water and heat required for humidification is supplied by the cooling system [47]. 
The cooling system can use a fan for lower power fuel cells or drive water through the stack using pumps to transfer heat from the fuel cell to the hull [51]. It uses the liquid water that is separated from the reactants and is collected in the tank for the cooling of the stack and for humidification of both reactant gases. The heat from the stack is rejected through a water cooled heat exchanger [47].

The electrical subsystem includes a constant voltage regulation system, a smart battery charger, an electricity supply regulation system and a startup battery [51]. The voltage generated from the fuel cell ranges from the open circuit voltage to the nominal cell voltage and requires a DC/DC power conditioner for constant voltage electrical components such as pumps, solenoids and the controller typically operate on $24 \mathrm{~V} \mathrm{DC}$ The startup battery energizes the solenoid valves on the fuel and oxidant supply lines. When the fuel cell receives fuel and oxygen it takes over and recharges the battery $[47,53]$.

\subsection{Hybrid Systems}

In an AUV, a hybrid fuel cell-battery system would improve upon the performance of either of these separate systems. Both components would be of smaller dimensions and would operate with higher efficiency because neither would have to provide full power [51]. On the other hand, in a non-hybrid fuel cell system the stack must be sized to the maximum required power.

In a hybrid fuel cell system two different system configurations are identified. In a first scenario the fuel cell constantly supplies power at maximum efficiency. When power demand is low the fuel cell recharges the batteries and supplies power to the load. The batteries provide the remaining power at times of high demand [10,47]. This approach presents the issue that when the battery provides all the power to the load, the fuel cell is switched out of the circuit with it still consuming oxidant and fuel [10]. In a second scenario, all the power would be supplied from the batteries, while the fuel cell is used for recharging $[47,54]$.

\section{Estimation of Energy Parameters on an Example AUV}

Knowing the energy parameters of different storage systems, the mass and volume of the complete power plant can be taken into account to calculate the energy parameters of the whole power system, for different storage solutions [55]. These estimates can be then compared to standard energy storage solutions, as are lithium-ion batteries.

In this section a couple different storage solutions, which are considered to be representative, will be analyzed as an example. In order to do this a $1 \mathrm{~kW}$ AUV with 72-h endurance will be examined, which is accurate for medium to large size vehicles. In this example, two different Horizon fuel cell stacks and three different storage combinations are used, thus providing six power system combinations. The Horizon fuel cell stacks are the Aerostack A1000 PEM and the Horizon H-1000, which were included in Table 2. They were chosen because of the high quality of Horizon fuel cells, and their proven experience in multiple fuel cell powered UAVs. They also cover a wide power density range, from 250 to $570 \mathrm{~W} / \mathrm{kg}$, and so are considered to be a representative enough sample for this estimate. Both of these fuel cells have some integrated balance of plant components, but in order to account for the closed cycle design necessary for the air independent propulsion requirement imposed on AUVs, total balance of plant component weight and size have been estimated from data taken from [56]. In this study, an integrated fuel cell power system was designed to be adapted into an 
existing military vehicle with great volume and weight constraints. This data is considered to be a good estimation because a hypothetical commercial fuel cell system would be designed optimizing these same parameters. The weight and volume of the total fuel cell system can be seen in Table 5 .

Table 5. Example stacks weight and volume.

\begin{tabular}{ccc}
\hline Fuel Cell Stack & Fuel Cell System Weight (kg) & Fuel Cell System Volume (L) \\
\hline Aerostack A1000 PEM & 31.75 & 37.20 \\
Horizon H-1000 & 34.00 & 40.00 \\
\hline
\end{tabular}

The reactant storage combinations considered were liquid hydrogen/liquid oxygen, compressed hydrogen/compressed oxygen and metal hydride/compressed oxygen.

The energy density (ED) and specific energy (SE) of the complete storage system are calculated, assuming the storage system components are sized to the same energy, as [19]:

$$
\begin{gathered}
\mathrm{ED}_{\mathrm{SS}}=\frac{\mathrm{ED}_{\mathrm{H}_{2}} \mathrm{ED}_{\mathrm{O}_{2}}}{\mathrm{ED}_{\mathrm{H}_{2}}+\mathrm{ED}_{\mathrm{O}_{2}}} \\
\mathrm{SE}_{\mathrm{SS}}=\frac{\mathrm{SE}_{\mathrm{H}_{2}} \mathrm{SE}_{\mathrm{O}_{2}}}{\mathrm{SE}_{\mathrm{H}_{2}}+\mathrm{SE}_{\mathrm{O}_{2}}}
\end{gathered}
$$

For the system's energy density and specific energy calculation, the supposition is made that the whole system's mass and weight is the sum of that of the storage and the fuel cell system. The results are presented in Table 6.

\begin{tabular}{|c|c|c|c|c|c|c|}
\hline \multirow{2}{*}{ Storage Combination } & \multicolumn{2}{|c|}{ Storage System } & \multicolumn{2}{|c|}{ Total System (Aeropack) } & \multicolumn{2}{|c|}{ Total System (H-1000) } \\
\hline & $\mathrm{ED}(\mathrm{Wh} / \mathrm{L})$ & $\mathrm{SE}(\mathrm{Wh} / \mathrm{kg})$ & $\mathrm{ED}(\mathrm{Wh} / \mathrm{L})$ & $\mathrm{SE}(\mathrm{Wh} / \mathrm{kg})$ & $\mathrm{ED}(\mathrm{Wh} / \mathrm{L})$ & $\mathrm{SE}(\mathrm{Wh} / \mathrm{kg})$ \\
\hline LOX/LH2 & 850 & 1052 & 590 & 719 & 577 & 703 \\
\hline $\mathrm{GasO}_{2} / \mathrm{Gas} \mathrm{H}_{2}$ & 323 & 624 & 277 & 489 & 274 & 482 \\
\hline Met Hydri/Gas $\mathrm{O}_{2}$ & 428 & 271 & 350 & 242 & 346 & 240 \\
\hline
\end{tabular}

Table 6. Energy density and specific energy for storage and total system.

Lithium-Ion batteries have energy densities between $329 \mathrm{Wh} / \mathrm{L}$ and $490 \mathrm{Wh} / \mathrm{L}$ and specific energy's between $165 \mathrm{Wh} / \mathrm{kg}$ and $207 \mathrm{Wh} / \mathrm{kg}$ [57,58]. From the approximate results shown in Table 6, it can be seen that for these combinations, there is significant improvement on the specific energy of the fuel cell power systems, when compared to lithium ion ones, and the energy density is also higher in the optimal cryogenic storage solution, and has similar values to lithium-ion in the remaining ones.

\section{Conclusions}

The current development of fuel cell powered AUVs has been overviewed. Interested researchers in this field can find the information given very useful to gain insight into the fuel cell AUV's technology development. It has been shown how limited progress has been in this field due to the complexity and high costs involved. Only two fuel cell AUV prototypes have been constructed, and several bench AUV fuel cell power systems have been tested out of the water. 
At this time interest in autonomous unmanned systems is high and in the case of AUVs, in order for serious development to be achieved, system endurance must necessarily be increased. Fuel cell powered systems have been shown to have higher specific energies than the more commonly used lithium-ion batteries, and also comparable to higher energy densities depending on the specific storage system used. This fact has been evidenced by its successful implementation in UAVs, breaking several flight endurance records. And it has also been evidenced in the multi-million dollar investment of the US Navy in the development of these systems. A lot of work needs to be done in compact, lightweight, efficient integrated fuel cell power systems, with a special focus on reactant storage optimization.

One of the avenues to achieving greater endurances is through the use of hybrid fuel cell-secondary battery power systems that allow the possibility to increase the overall efficiency while reducing component sizes.

\section{Acknowledgments}

The authors gratefully acknowledge the Spanish Ministry of Economy and Competitiveness (Project ENE2011-28735-C02-02) and the E.T.S.I. Navales from the Universidad Politécnica de Madrid (Spain) for its support and help. The authors gratefully acknowledge ETSI Navales (UPM) Library Staff for the help received.

\section{Author Contributions}

All co-authors have made important contributions to the conception and design of this paper, as well as to the acquisition, analysis or interpretation of data. The review task for data collection has been thoroughly and especially carried out by Mr. Alejandro Mendez. All of the co-authors have been also involved in drafting and revising the manuscript, so that everyone has given final approval of the current version to be published in Energies.

\section{Conflicts of Interest}

The authors declare no conflict of interest.

\section{References}

1. Yuh, J.; Marani, G.; Blidberg, D.R. Applications of marine robotic vehicles. Intel. Serv. Robot. 2011, 4, 221-231.

2. Lee, Y.-D.E.; George, R.A. High-resolution geological AUV survey results across a portion of the eastern Sigsbee Escarpment. Am. Assoc. Pet. Geol. Bull. 2004, 88, 747-764.

3. Bradley, A.M.; Feezor, M.D.; Singh, H.; Sorrell, F.Y. Power systems for autonomous underwater vehicles. IEEE J. Ocean. Eng. 2001, 26, 526-538.

4. Swider-Lyons, K.E.; Carlin, R.T.; Rosenfeld, R.L.; Nowak, R.J. Technical issues and opportunities for fuel cell development for autonomous underwater vehicles. In Proceedings of the 2002 Workshop on Autonomous Underwater Vehicles, Taibei, Taiwan, 21 June 2002; pp. 61-64. 
5. Wang, X.; Shang, J.; Luo, Z.; Tang, L.; Zhang, X.; Li, J. Reviews of power systems and environmental energy conversion for unmanned underwater vehicles. Renew. Sustain. Energy Rev. 2012, 16, 1958-1970.

6. Sawa, T.; Aoki, T.; Yamamoto, I.; Tsukioka, S.; Yoshida, H.; Hyakudome, T.; Ishibashi, S.; Inada, T.; Kabeno, T.; Sasamoto, R.; et al. Performance of the fuel cell underwater vehicle urashima. Acoust. Sci. Technol. 2005, 26, 249-257.

7. Ishibashi, S.; Aoki, T.; Tsukioka, S.; Yoshida, H.; Inada, T.; Kabeno, T.; Maeda, T.; Hirokawa, K.; Yokoyama, K.; Tani, T.; et al. In An ocean going autonomous underwater vehicle "urashima" equipped with a fuel cell. In Proceedings of 2004 International Symposium on Underwater Technology, Taibei, Taiwan, 20-23 April 2004; pp. 209-214.

8. Yamamoto, I.; Aoki, T.; Tsukioka, S.; Yoshida, H.; Hyakudome, T.; Sawa, T.; Ishibashi, S.; Inada, T.; Yokoyama, K.; Maeda, T.; et al. Fuel cell system of AUV "Urashima". In Proceedings of OCEANS '04. MTTS/IEEE TECHNO-OCEAN '04, Kobe, Japan, 9-12 November 2004; pp. 1732-1737.

9. Maeda, T.; Ishiguro, S.; Yokoyama, K.; Hirokawa, K.; Hisatome, N.; Tani, T. Fuel Cell AUV "URASHIMA". Mitsubishi Heavy Ind. Tech. Rev. 2006, 43, 24-25.

10. Griffiths, G.; Reece, D.; Blackmore, P.; Lain, M.; Mitchell, S.; Jamieson, J. Modeling hybrid energy systems for use in AUVs. In Proceedings of the 14th Unmanned Untethered Submersible Technology, Durham, NC, USA, 21-24 August 2005; pp. 1-10.

11. Tsukioka, S.; Aoki, T.; Yamamoto, I.; Yoshida, H.; Hyakudome, T.; Ishibashi, S.; Sawa, T.; Ishikawa, A.; Hirokawa, K. Results of a long distance experiment with the AUV "Urashima". In Proceedings of OCEANS '04. MTTS/IEEE TECHNO-OCEAN '04, Kobe, Japan, 9-12 November 2004; pp. 1714-1719.

12. Hyakudome, T.; Yoshida, H.; Nakatani, T.; Ohta, Y.; Tani, T.; Sugihara, K.; Moriga, T.; Iwamoto, T.; Kawaharazaki, Y.; Oda, T.; et al. Development of fuel cell system for underwater power source. In Proceedings of 2013 MTS/IEEE OCEANS-Bergen, Bergen, Norway, 10-14 June 2013; pp. 1-6.

13. Yoshida, H.; Sawa, T.; Hyakudome, T.; Ishibashi, S.; Tani, T.; Iwata, M.; Moriga, T. The high efficiency multi-less (HEML) fuel cell—A high energy source for underwater vehicles, buoys, and stations. In Proceedings of IEEE OCEANS, Santander, Spain, 6-9 June 2011; pp. 1-6.

14. Mitsubishi Heavy Industries, Ltd. Available online: https://www.mhi-global.com/ (accessed on 7 July 2014).

15. Hornfeld, W. DeepC: The new deep water AUV generation. In Proceedings of the 22nd International Conference of Offshore Mechanics and Artic Engineering, Cancun, Mexico, 8-13 June 2003; pp. 713-721.

16. Raugel, E.; Rigaud, V.; Lakeman, C. Sea experiment of a survey auv powered by a fuel cell system. In Proceedings of 2010 IEEE/OES Autonomous Underwater Vehicles (AUV), Monterey, CA, USA, 1-3 September 2010; pp. 1-3.

17. Wu, J.-G.; Chen, C.-Y.; Zhang, H.-W.; Xie, C.-G.; Wang, X.-M. In Study on well-to-drag efficiency of pemfc powered glider. In Proceedings of 4th IEEE Conference on Industrial Electronics and Applications, Xi'an, China, 25-27 May 2009; pp. 1970-1975. 
18. The Pennsylvania State University, H2E Center. Available online: http://www.engr.psu.edu/h2e/ Professors/Dr._Klanchar,_Martin/Fuel\%20Cell\%20Systems\%20for\%20Undersea\%20Propulsion\% 20\%20Dr.\%20Klanchar.pdf (accessed on 31 May 2013).

19. Davies, K.L.; Moore, R.M. UUV FCEPS Technology Assessment and Design Process. Available online: http://web41.its.hawaii.edu/www.hnei.hawaii.edu/sites/web41.its.hawaii.edu.www.hnei. hawaii.edu/files/page/2010/06/UUV_FCEPS_ReportRev5.pdf (accessed on 18 July 2014).

20. U.S. Navy. The Navy Unmanned Undersea Vehicle (UUV) Master Plan. Available online: http://www.navy.mil/navydata/technology/uuvmp.pdf (accessed on 18 July 2014).

21. Office of Naval Research. Long Endurance Undersea Vehicle Propulsion. Office of Naval Research. Available online: https://www.fbo.gov/index?s=opportunity\&mode=form\&id= 012446f173f12e1d6ed4aba14e13f0f1\&tab=core\&_cview=1 (accessed on 18 July 2014).

22. Davies, K.L.; Moore, R.M. Unmanned underwater vehicle fuel cell energy/power system technology assessment. IEEE J. Ocean. Eng. 2007, 32, 365-372.

23. Rosenfeld, R.L.; Prokopius, P.R.; Meyer, A.P. In Fuel cell power system development for submersibles. In Proceedings of the 1992 Symposium on Autonomous Underwater Vehicle Technology, Washington, WA, USA, 2-3 June 1992; pp. 184-188.

24. Roy, R. Development of a Power and Energy Storage System for Unmanned, Undersea Vehicles (UUVs). Available online: http://www.fuelcellseminar.com/media/51137/b2b24-1.pdf (accessed on 18 July 2014).

25. Utc aerospace systems. S-80 fuel cell power module. Available online: http://utcaerospacesystems. com/cap/products/Pages/fuel-cell-power-module.aspx (accessed on 31 May 2014).

26. Swartz, S.L.; Arkenberg, G.B.; Thrun, L.B.; Sellers, C.T.; Emerick, J.S. SOFC-Based UUV Energy System. Available online: http://www.fuelcellseminar.com/media/51140/b2b24-2.pdf (accessed on 18 July 2014).

27. Presley, K.; Swartz, S. A New Oxygen Source for SOFC Based Power Systems for Long Duration UUVs. Available online: http://www.fuelcellseminar.com/media/51275/b2b42-3.pdf (accessed on 18 July 2014).

28. Infinity-air independent fuel cells. Available online: http://www.infinityfuel.com/products/ air-independent-fuel-cells/ (accessed on 31 May 2014).

29. Bever, D. Energy and Power System for ONR's LDUUV Program. Available online: http://www.fuelcellseminar.com/media/51188/b2b32-2-1.pdf (accessed on 18 July 2014).

30. Rhodes, J.; Fenimore, F.; Hennings, B. Long Endurance Fuel Cell Energy System For Unmanned Undersea Vehicles. Available online: http://www.fuelcellseminar.com/media/51272/b2b42-2.pdf (accessed on 18 July 2014).

31. Navy sbir/sttr. Available online: http://www.navysbir.com/docs/Sierra_FINAL_ONR.pdf (accessed on 31 May 2014).

32. Fuelcell energy wins $\$ 3.8 \mathrm{~m}$ contract for unmanned underwater vehicle power system. Available online: http://www.unmannedsystemstechnology.com/2012/07/fuelcell-energy-wins-38m-ontract-for-unmanned-underwater-vehicle-power-system/ (accessed on 31 May 2014).

33. Lee, C.-H.; Yang, J.-T. Modeling of the ballard-mark-v proton exchange membrane fuel cell with power converters for applications in autonomous underwater vehicles. J. Power Sources 2011, 196, 3810-3823. 
34. Dudek, M.; Tomczyk, P.; Wygonik, P.; Korkosz, M.; Bogusz, P.; Lis, B. Hybrid fuel cell-battery system as a main power unit for small Unmanned Aerial Vehicles (UAV). Int. J. Electrochem. Sci. 2013, $8,8442-8463$.

35. Protonex fuel cell power system for uav now commercially available. Available online: http://www.fuelcelltoday.com/news-events/news-archive/2012/august/protonex-fuel-cell-powersystem-for-uav-now-commercially-available (accessed on 31 May 2014).

36. González-Espasandín, Ó.; Leo, T.J.; Navarro-Arévalo, E. Fuel Cells: A Real Option for Unmanned Aerial Vehicles Propulsion. Sci. World J. 2014, 497642:1-497642:12.

37. Ballard product. Available online: http:/www.ballard.com/files/PDF/ProductPortfolio.pdf (accessed on 31 May 2014).

38. Quintech catalog download. Available online: http://www.quintech.de/englisch/special-offer.php (accessed on 31 May 2014).

39. Aps physics-Ion tiger. Available online: http://www.aps.org/units/gera/meetings/march10/ upload/Swider-LyonsAPS3-14-10.pdf (accessed on 31 May 2014).

40. Energyor product brochure. Available online: http://www.energyor.com/energyor/pdf/ EnergyOr\%20EPOD\%20EO-310-XLE\%20Product\%20Brochure\%20-\%20Version\%201.2.pdf (accessed on 31 May 2014).

41. Horizon fuel cells aerostack borchure. Available online: http://media.wix.com/ugd/ 047f54_5efe66b2736846bb8d25a7a326559c84.pdf (accessed on 31 May 2014).

42. Horizon fuel cells pem borchure. Available online: http://media.wix.com/ugd/047f54 8728bcd6c312a384c513237545f289ae.pdf (accessed on 31 May 2014).

43. H-1000 fuel cell stackuser manual. Available online: http://media.wix.com/ugd/047f54 86b712599dda8542adcca251d9904ca4.pdf (accessed on 31 May 2014).

44. $2000 \mathrm{w}$ fuel cell stack user. Available online: http://media.wix.com/ugd/047f54 86b712599dda8542adcca251d9904ca4.pdf (accessed on 31 May 2014).

45. Nedstack pem fuel cell product specifications. Available online: http://www.nedstack.com/ images/stories/products/nedstack_product-specifications-of-hp-stacks.pdf (accessed on 31 May 2014).

46. Zentrum für Sonnenenergie- und Wasserstoff-Forschung (ZSW). Available online: http://www. zsw-bw.de/en/topics/fuel-cells/components-and-stacks.html (accessed on 31 May 2014).

47. Barbir, F. In Proton exchange membrane fuel cell technology status and applicability for propulsion of autonomous underwater vehicles. In Proceedings of the 2002 Workshop on Autonomous Underwater Vehicles, Taibei, Taiwan, 21 June 2002; pp. 65-69.

48. Baumert, R.; Epp, D. Hydrogen storage for fuel cell powered underwater vehicles, In Proceedings of Engineering in Harmony with Ocean, Victoria, BC, Canada, 18-21 October 1993; pp. 166-171.

49. Gish, L. A. Design of an AUV Recharge System. Master Thesis, Massachusetts Institute of Technology: Cambridge, MA, USA, June 2004.

50. Hyakudome, T. Design of autonomous underwater vehicle. Int. J. Adv. Robot. Syst. 2011, 8, 131-139

51. Cai, Q.; Browning, D.J.; Brett, D.J.; Brandon, N.P. Hybrid fuel cell/battery power systems for underwater vehicles. In Proceedings of 3rd SEAS DTC Technical Conference, Edinburgh, UK, 24-25 June 2008. 
52. Hyakudome, T.; Yoshida, H.; Tsukioka, S.; Sawa, T.; Ishibashia, S.; Aoki, T.; Iwamoto, T.; Kawaharazaki, Y.; Muto, A.; Oda, T.; et al. High Efficiency Hydrogen and Oxygen Storage System Development for Underwater Platforms Powered by Fuel Cell. ECS Trans. 2010, 26, 465-474.

53. Hasvold, O.; Johansen, K.H. The alkaline aluminium hydrogen peroxide semi-fuel cell for the hugin 3000 autonomous underwater vehicle. In Proceedings of the 2002 Workshop on Autonomous Underwater Vehicles, Taibei, Taiwan, 18 June 2002; pp. 89-94.

54. Cai, Q.; Brett, D.J.L.; Browning, D.; Brandon, N.P. A sizing-design methodology for hybrid fuel cell power systems and its application to an unmanned underwater vehicle. J. Power Sour. 2010, 195, 6559-6569.

55. Takagawa, S. In Feasibility study on dmfc power source for underwater vehicles. In Proceedings of Symposium on Underwater Technology and Workshop on Scientific Use of Submarine Cables and Related Technologies, Tokyo, Japan, 17-20 April 2007; pp. 326-330.

56. Andrukaitis, E.E. Fuel Cells as Tactical Auxiliary Power in Military Vehicles. ECS Trans. 2010, 26, 445-454.

57. Boston power-Data sheets. Available online: http://www.boston-power.com/resources/ data-sheets (accessed on 31 May 2014).

58. Henderson, E.; Pantelakis, T.; An, E. Energy systems for FAU AUVs [autonomous underwater vehicles]. In Proceedings of the 2002 Workshop on Autonomous Underwater Vehicles, Taibei, Taiwan, 18 June 2002; pp. 5-10.

(C) 2014 by the authors; licensee MDPI, Basel, Switzerland. This article is an open access article distributed under the terms and conditions of the Creative Commons Attribution license (http://creativecommons.org/licenses/by/3.0/). 